University of Nebraska - Lincoln

DigitalCommons@University of Nebraska - Lincoln

Faculty Publications: Department of Entomology

Entomology, Department of

January 1993

Comparative Toxicity of Pyrethroid Insecticides to Terrestrial and Aquatic Insects

Blair Siegfried

University of Nebraska-Lincoln, bsiegfried1@ufl.edu

Follow this and additional works at: https://digitalcommons.unl.edu/entomologyfacpub

Part of the Entomology Commons

Siegfried, Blair, "Comparative Toxicity of Pyrethroid Insecticides to Terrestrial and Aquatic Insects" (1993). Faculty Publications: Department of Entomology. 132.

https://digitalcommons.unl.edu/entomologyfacpub/132

This Article is brought to you for free and open access by the Entomology, Department of at DigitalCommons@University of Nebraska - Lincoln. It has been accepted for inclusion in Faculty Publications: Department of Entomology by an authorized administrator of DigitalCommons@University of Nebraska - Lincoln. 
Published in Environmental Toxicology and Chemistry 12 (1993), pp 1683-1689.

Copyright (C) 1993 SETAC; published by Pergamon Press Ltd./Elsevier. Used by permission.

Journal Series Paper 10056, Nebraska Agricultural Research Division,

and Contribution 806 of the Department of Entomology, University of Nebraska-Lincoln.

Submitted August 4, 1992; accepted January 5, 1993.

\title{
Comparative Toxicity of Pyrethroid Insecticides to Terrestrial and Aquatic Insects
}

\author{
Blair D. Siegfried \\ Department of Entomology, 202 Plant Industry Building, \\ University of Nebraska-Lincoln, Lincoln, Nebraska 68583
}

\begin{abstract}
The acute toxicities of three pyrethroid insecticides (permethrin, cypermethrin, and bifenthrin) and one organophosphate insecticide (chlorpyrifos) were compared by topical application and static exposure to a variety of terrestrial and aquatic insects. Mayflies and damselflies were the most susceptible taxa tested by both exposure methods. The aquatic insects were generally more susceptible than the terrestrial insects when compared on a dose per body weight basis, although the differences were smaller than expected, given the extremely low concentrations that produce toxic effects by static exposure.
\end{abstract}

Keywords: Synthetic pyrethroids, topical bioassay, terrestrial and aquatic insects

\section{INTRODUCTION}

Synthetic pyrethroid insecticides have been developed for major uses in agriculture and public health. Modern synthetic pyrethroids are exceptionally active against many insects yet are safe to mammals and birds [1-5]. Perhaps the biggest hindrance to a wider role of pyrethroids in agriculture is their extreme toxicity to aquatic organisms [6]. Numerous reports indicate that aquatic insects are highly sensitive to pyrethroid poisoning, based on the extremely low concentrations (often $<1 \mu \mathrm{g} / \mathrm{L}$ ) that produce toxic effects [7-9]. However, all of these accounts concern acute toxicity tests in which the insects are exposed to insecticides diluted in water with toxicity expressed as lethal concentration. Toxicity testing of aquatic organisms is limited by a lack of information on the body toxicant concentration at the biological response end point in question [10-12]. Aquatic organisms are exposed to toxicants in water and to chemicals complexed with food, particulates, and dissolved organic material. Estimating dose to the animal therefore presents a difficult challenge [12]. Because of the inherent difficulties in determining a lethal dose of insecticide for aquatic insects, it has not been possible to compare susceptibility of aquatic insects to that of other organisms. In addition, there is some indication that different aquatic insects vary considerably in their response to insec- ticides, based on static exposure tests [7], but comparisons of toxicity based on insecticide doses have thus far not been possible.

This study was conducted to determine the relative toxicity of pyrethroid insecticides (permethrin, cypermethrin, and bifenthrin) and one organophosphate (chlorpyrifos) to a variety of aquatic and terrestrial insects. Because most aquatic insects can survive for extended periods (up to $48 \mathrm{~h}$ ) in the absence water (personal observation), bioassays were conducted by topical application and treated insects were maintained out of water to prevent the insecticide from being washed off into the surrounding medium, thus allowing LD50s to be calculated on the basis of dose per body weight so that comparisons of toxicity between aquatic and terrestrial insects could be made.

\section{MATERIALS AND METHODS}

\section{Chemicals}

Three pyrethroid and one organophosphate insecticide were bioassayed against terrestrial and aquatic insects. Technical-grade permethrin ( $96 \%$ purity) and bifenthrin (94\% purity) were supplied by the FMC Corp. (Princeton, NJ). Technical-grade chlorpyrifos ( $99 \%$ purity) was obtained from Dow Chemical Co. (Midland, MI). Technical-grade cypermethrin (99.4\% purity) was purchased as an analytical standard from Crescent Chemical Co. (Hauppauge, NY). 
Insects

Five taxa of aquatic insects were chosen for bioassay of pyrethroid insecticides. Insects were chosen for inclusion in this work on the basis of autecologies (i.e., free swimming vs. attached, predators vs. scavengers, those that derive oxygen from water vs. those that derive oxygen from air). Additional criteria for selection included availability, synchronicity of life cycle, and size, in order to minimize variability in response of the tested populations and to obtain insects large enough to allow topical application of insecticide. Collection site, taxonomic status, and developmental stage or size for the five groups are listed in Table 1. Because most of the tested aquatic insects represent a mixture of species, identifications to the family or generic level have been assigned. For purposes of analysis, each group was treated as a single taxon.

Aquatic insects were collected from the field and returned to the laboratory in petri dishes containing water obtained from the collection site. The insects were then refrigerated at $4^{\circ} \mathrm{C}$ within collection dishes and maintained for up to $72 \mathrm{~h}$ without significant mortality, eliminating the need for feeding and long-term maintenance. The colder temperatures were used for maintenance because survival at room temperature was drastically reduced compared to insects maintained at $4^{\circ} \mathrm{C}$.

In addition to the aquatic species, three terrestrial insects were bioassayed for comparative purposes. Third-instar housefly, Musca domestica L., larvae were obtained from a laboratory colony maintained by the U.S. Department of Agriculture (USDA) Livestock Research Lab at the University of Nebraska-Lincoln. Convergent lady beetle, Hippodamia convergens Guerin-Meneville, adults were purchased from Ward Natural Sciences Establishment
Inc. (Rochester, NY), European corn borer, Ostrinia nubilalis (Hubner), were purchased as third-instar larvae from French Agricultural Research (Lamberton, $\mathrm{MN}$ ).

\section{Bioassays}

Bioassays of both terrestrial and aquatic insects were conducted by topical application of insecticide diluted in acetone $(0.5 \mu \mathrm{l})$ to the ventral abdomen of each insect. After treatment, the insects were held in disposable plastic petri dishes $(10-\mathrm{cm}$ diam. $\times 1-\mathrm{cm}$ height) lined with moistened filter paper (Whatman, Clifton, NJ) at $20^{\circ} \mathrm{C}$ without light. Mortality was assessed by the inability of treated insects to respond to probing with a dissecting needle and was recorded $24 \mathrm{~h}$ after treatment. Experimental mortality was corrected for control mortality in which insects were treated with acetone only. Control mortality was $<10 \%$, except for black flies, which exhibited $17 \%$ mortality, and mayflies, which exhibited $18 \%$ mortality in controls. LD50s were calculated as dose of a.i. insecticide per milligram body weight. To obtain mean body weights, individual insects were blotted dry on paper towels and weighed. Samples of 30 insects were weighed for each bioassay.

In addition to the topical bioassays, static bioassays of insecticides diluted in water were conducted. Each compound was diluted in $15 \mathrm{ml}$ distilled water, and groups of five or 10 insects exposed in glass petri dishes $(5-\mathrm{cm}$ diam. $\times 1-\mathrm{cm}$ height). Mortality was recorded after $24 \mathrm{~h}$ and corrected for control mortality, in which insects were exposed to distilled water only. Control mortality was $<10 \%$, except for black flies, which exhibited $14 \%$ mortality, and mayflies, which exhibited $16 \%$ mortality, in controls. All bioassays were conducted at $20^{\circ} \mathrm{C}$ in the absence of light.

Table 1. Aquatic insects chosen for insecticide bioassays

\begin{tabular}{|c|c|c|c|}
\hline Insect & Collection site & & Developmental stage \\
\hline $\begin{array}{l}\text { Black fly } \\
\quad \text { Simullum vitattum }\end{array}$ & $\begin{array}{l}\text { Hanes Branch, } \\
\text { Lancaster Co., NE }\end{array}$ & & Larva $(5-7 \mathrm{~mm})$ \\
\hline $\begin{array}{l}\text { Caddısfly } \\
\text { Hydropsyche and Cheumatopsyche spp. }\end{array}$ & $\begin{array}{l}\text { Hanes Branch, } \\
\text { Lancaster Co., NE }\end{array}$ & & Larva $(8-10 \mathrm{~mm})$ \\
\hline $\begin{array}{l}\text { Mayfly } \\
\text { Heptageniidae }\end{array}$ & $\begin{array}{l}\text { Bear Creek, } \\
\text { Gage Co., NE }\end{array}$ & & Nymph $(8-12 \mathrm{~mm})$ \\
\hline $\begin{array}{l}\text { Damselfly } \\
\text { Enellagma and Ishnura spp. }\end{array}$ & $\begin{array}{l}\text { Killdeer Lake, } \\
\text { Lancaster Co., NE }\end{array}$ & ' & Nymph $(10-15 \mathrm{~mm})$ \\
\hline $\begin{array}{l}\text { Water scavenger beetle } \\
\text { Hydrophilus spp. }\end{array}$ & $\begin{array}{l}\text { Killdeer Lake, } \\
\text { Lancaster Co., NE }\end{array}$ & & Adult \\
\hline
\end{tabular}


Bioassays for both exposure methods consisted of at least three insecticide concentrations or doses giving mortality $>0$ and $<100 \%$, and each experiment was replicated at least three times. LD50s and LC50s were determined by probit analysis adapted for personal computer use [13].

\section{RESULTS}

Results of topical bioassays for terrestrial and aquatic insects appear in Table 2. Data are also presented in Figure 1 for visual comparisons. The general trend of toxicity of the four compounds across taxa was bifenthrin $=$ cypermethrin $>$ permethrin $\geq$ chlorpyrifos. For all compounds, LD50 values were generally higher for the terrestrial insects, although there were some notable exceptions. For the three pyrethroid insecticides, European corn borer was as susceptible as most of the aquatic insects. Of the aquatic insects, water scavenger beetles exhibited susceptibility similar to that of the terrestrial insects. Mayflies and damselflies were the most susceptible to all tested insecticides. For all the terrestrial insects, cypermethrin and bifenthrin were the most toxic of the four tested compounds. In contrast to the terrestrial insects, the pattern of toxicity was much less consistent in the aquatic insects. Generally, bifenthrin and cypermethrin were again the most toxic of the tested compounds, but the level of difference among the four compounds was less than that observed for terrestrial insects.

Table 2. Relative toxicity of topically applied chlorpyrifos, permethrin, cypermethrin, and bifenthrin to selected aquatic and terrestrial insects

\begin{tabular}{|c|c|c|c|c|c|}
\hline Taxa & Insecticide & $N$ & $\mathrm{LD}^{\mathrm{a}}{ }^{\mathrm{a}}$ & $95 \%$ C.L. $^{b}$ & Slope $\pm S E$ \\
\hline Black fly & $\begin{array}{l}\text { Chlorpyrifos } \\
\text { Permethrin } \\
\text { Cypermethrin } \\
\text { Bifenthrin }\end{array}$ & $\begin{array}{l}240 \\
410 \\
300 \\
290\end{array}$ & $\begin{array}{l}8.6 \\
5.2 \\
1.8 \\
1.1\end{array}$ & $\begin{array}{c}6.0-11 \\
3.5-7.3 \\
1.0-2.7 \\
0.76-1.5\end{array}$ & $\begin{array}{r}1.9 \pm 0.27 \\
1.3 \pm 0.15 \\
0.95 \pm 0.15 \\
1.5 \pm 0.20\end{array}$ \\
\hline Caddisfly & $\begin{array}{l}\text { Chlorpyrifos } \\
\text { Permethrin } \\
\text { Cypermethrin } \\
\text { Bifenthrin }\end{array}$ & $\begin{array}{l}285 \\
465 \\
470 \\
520\end{array}$ & $\begin{array}{l}1.0 \\
2.8 \\
1.2 \\
3.2\end{array}$ & $\begin{array}{r}0.63-1.7 \\
1.7-4.5 \\
0.88-1.6 \\
2.0-5.4\end{array}$ & $\begin{array}{r}0.74 \pm 0.12 \\
1.3 \pm 0.30 \\
1.1 \pm 0.12 \\
0.71 \pm 0.10\end{array}$ \\
\hline Mayfly & $\begin{array}{l}\text { Chlorpyrifos } \\
\text { Permethrin } \\
\text { Cypermethrin } \\
\text { Bifenthrin }\end{array}$ & $\begin{array}{l}380 \\
320 \\
160 \\
160\end{array}$ & $\begin{array}{l}3.2 \\
0.73 \\
0.92 \\
0.22\end{array}$ & $\begin{array}{l}2.8-5.0 \\
0.47-1.0 \\
0.38-1.6 \\
0.14-0.32\end{array}$ & $\begin{array}{l}1.6 \pm 0.18 \\
1.5 \pm 0.23 \\
1.2 \pm 0.23 \\
1.9 \pm 0.34\end{array}$ \\
\hline Damselfly & $\begin{array}{l}\text { Chlorpyrifos } \\
\text { Permethrin } \\
\text { Cypermethrin } \\
\text { Bifenthrin }\end{array}$ & $\begin{array}{l}280 \\
210 \\
170 \\
160\end{array}$ & $\begin{array}{l}0.91 \\
0.94 \\
0.30 \\
0.10\end{array}$ & $\begin{array}{c}0.75-1.3 \\
0.58-1.4 \\
0.18-0.46 \\
0.066-0.16\end{array}$ & $\begin{array}{l}3.0 \pm 0.37 \\
1.4 \pm 0.19 \\
1.2 \pm 0.19 \\
1.3 \pm 0.22\end{array}$ \\
\hline Diving beetle & $\begin{array}{l}\text { Chlorpyrifos } \\
\text { Permethrin } \\
\text { Cypermethrin } \\
\text { Bifenthrin }\end{array}$ & $\begin{array}{l}150 \\
200 \\
150 \\
200\end{array}$ & $\begin{array}{l}20 \\
11 \\
3.6 \\
4.0\end{array}$ & $\begin{array}{l}8.6-48 \\
7.9-16 \\
2.9-4.5 \\
2.4-7.4\end{array}$ & $\begin{array}{r}0.63 \pm 0.15 \\
1.4 \pm 0.18 \\
3.7 \pm 0.67 \\
0.83 \pm 0.14\end{array}$ \\
\hline European corn borer & $\begin{array}{l}\text { Chlorpyrifos } \\
\text { Permethrin } \\
\text { Cypermethrin } \\
\text { Bifenthrin }\end{array}$ & $\begin{array}{l}140 \\
180 \\
170 \\
170\end{array}$ & $\begin{array}{r}24 \\
3.9 \\
1.5 \\
1.1\end{array}$ & $\begin{array}{r}13-32 \\
2.7-5.4 \\
1.0-2.1 \\
0.74-1.5\end{array}$ & $\begin{array}{l}6.4 \pm 1.8 \\
2.0 \pm 0.30 \\
1.7 \pm 0.26 \\
1.8 \pm 0.26\end{array}$ \\
\hline Housefly & $\begin{array}{l}\text { Chlorpyrifos } \\
\text { Permethrin } \\
\text { Cypermethrin } \\
\text { Bifenthrin }\end{array}$ & $\begin{array}{l}650 \\
520 \\
350 \\
210\end{array}$ & $\begin{array}{l}60 \\
69 \\
49 \\
42\end{array}$ & $\begin{array}{c}44-93 \\
53-94 \\
35-68 \\
9.1-170\end{array}$ & $\begin{array}{c}0.99 \pm 0.12 \\
0.99 \pm 0.093 \\
1.2 \pm 0.15 \\
1.1 \pm 0.27\end{array}$ \\
\hline Lady beetle & $\begin{array}{l}\text { Chlorpyrifos } \\
\text { Permethrin } \\
\text { Cypermethrin } \\
\text { Bifenthrin }\end{array}$ & $\begin{array}{l}320 \\
240 \\
320 \\
200\end{array}$ & $\begin{array}{l}18 \\
39 \\
2.2 \\
6.5\end{array}$ & $\begin{array}{l}14-22 \\
18-130 \\
1.9-3.8 \\
3.1-16\end{array}$ & $\begin{array}{r}2.4 \pm 0.28 \\
0.50 \pm 0.13 \\
0.96 \pm 0.14 \\
0.56 \pm 0.13\end{array}$ \\
\hline
\end{tabular}

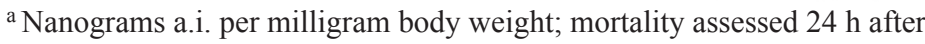
application.

b $95 \%$ confidence limit. 


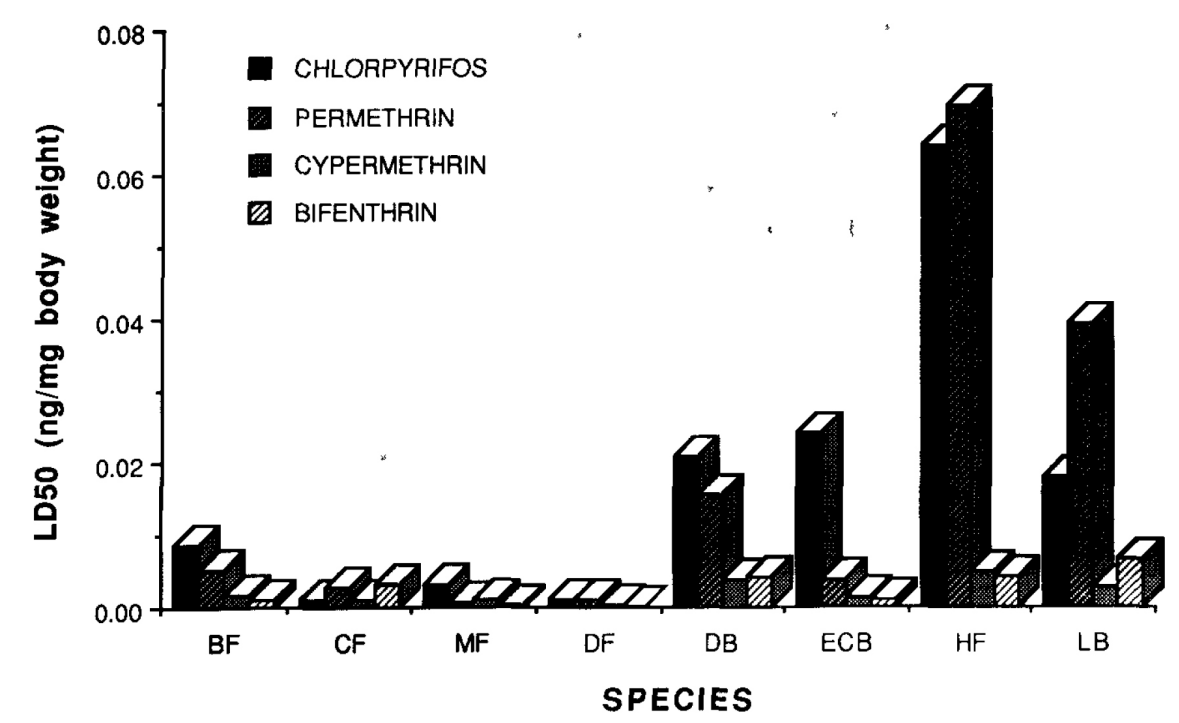

Figure 1. Comparative toxicity of chlorpyrifos, permethrin, cypermethrin, and bifenthrin by topical application to selected aquatic and terrestrial insects (aquatic insects: $\mathrm{BF}=$ black fly, $\mathrm{CF}=$ caddisfly, $\mathrm{MF}=$ mayfly, $\mathrm{DF}$ $=$ damselfly, $\mathrm{DB}=$ water scavenger beetle; terrestrial insects: $\mathrm{ECB}=$ European corn borer, $\mathrm{HF}=$ housefly, $\mathrm{LB}=$ convergent lady beetle).

LC50 values obtained by static bioassays of insecticide diluted in water appear in Table 3 and Figure 2. In all cases, chlorpyrifos was the least toxic of the tested compounds, with LC50 values significantly higher than any of the three pyrethroid insecticides, based on nonoverlapping $95 \%$ confidence limits. As noted for the topical bioassays, cypermethrin and bifenthrin were generally more toxic than permethrin.

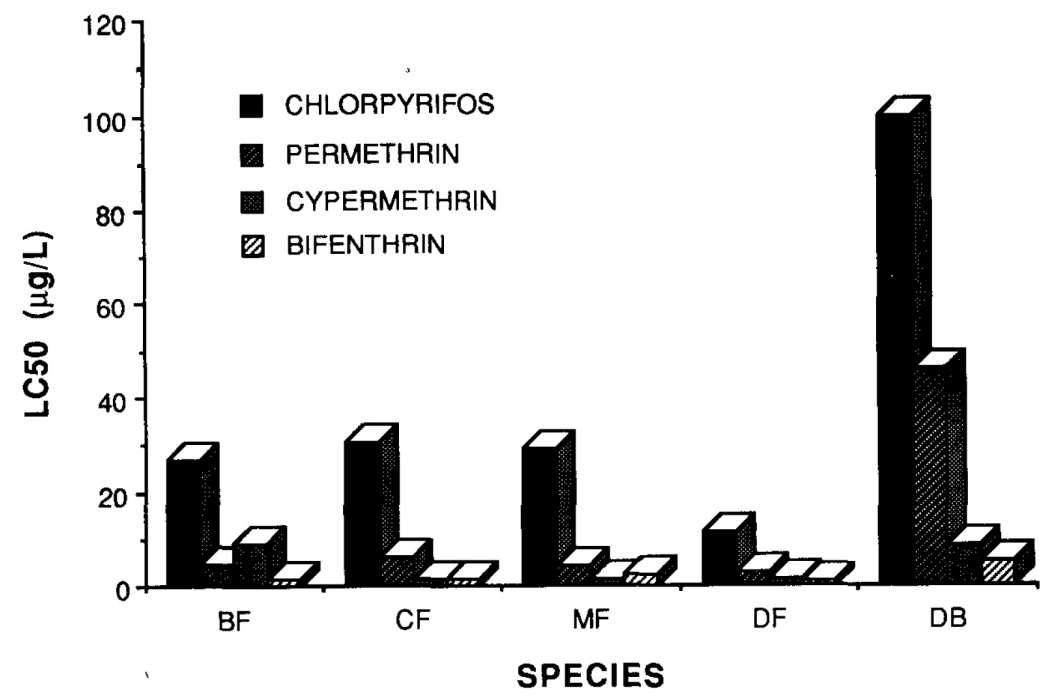

Figure 2. Comparative toxicity of chlorpyrifos, permethrin, cypermethrin, and bifenthrin to selected aquatic insects by static exposure to insecticide diluted in water $(\mathrm{BF}=$ black fly, $\mathrm{CF}=$ caddisfly, $\mathrm{MF}=$ mayfly, $\mathrm{DF}=\mathrm{dam}-$ selfly, DB = water scavenger beetle). 
Table 3. Toxicity of chlorpyrifos, permethrin, cypermethrin, and bifenthrin to selected aquatic insects by static exposure to insecticides diluted in water

\begin{tabular}{|c|c|c|c|c|c|}
\hline Taxa & Insecticide & $N$ & $\mathrm{LD}^{2} 0^{\mathrm{a}}$ & $95 \%$ C.L. $^{b}$ & Slope $\pm S E$ \\
\hline \multirow{4}{*}{ Black fly } & Chlorpyrifos & 120 & 27.0 & $19-34$ & $3.3 \pm 0.75$ \\
\hline & Permethrin & 120 & 4.5 & $3.0-6.4$ & $1.9 \pm 0.35$ \\
\hline & Cypermethrin & 180 & 9.8 & $1.8-15$ & $1.7 \pm 0.74$ \\
\hline & Bifenthrin & 240 & 1.3 & $0.16-11$ & $3.6 \pm 3.5$ \\
\hline \multirow[t]{4}{*}{ Caddisfly } & Chlorpyrifos & 120 & 30.6 & $19-46$ & $2.1 \pm 0.40$ \\
\hline & Permethrin & 120 & 5.9 & $2.8-10$ & $1.3 \pm 0.23$ \\
\hline & Cypermethrın & 120 & 1.4 & $0.81-2.0$ & $2.6 \pm 0.58$ \\
\hline & Bifenthrin & 120 & 7.2 & $4.5-10$ & $4.5 \pm 1.0$ \\
\hline \multirow[t]{4}{*}{ Mayfly } & Chlorpyrifos & 135 & 29 & $20-37$ & $4.2 \pm 0.97$ \\
\hline & Permethrin & 120 & 4.4 & $2.5-6.6$ & $2.4 \pm 0.69$ \\
\hline & Cypermethrin & 120 & 1.3 & $0.78-2.1$ & $2.8 \pm 0.56$ \\
\hline & Bifenthrin & 120 & 2.3 & $1.7-3.0$ & $3.6 \pm 0.79$ \\
\hline \multirow[t]{4}{*}{ Damselfly } & Chlorpyrifos & 180 & 11.4 & $8.6-14.3$ & $3.0 \pm 0.39$ \\
\hline & Permethrin & 150 & 2.9 & $2.2-3.8$ & $2.2 \pm 0.27$ \\
\hline & Cypermethrin & 100 & 1.4 & $0.92-2.0$ & $2.0 \pm 0.33$ \\
\hline & Bifenthrin & 120 & 1.1 & $0.68-1.7$ & $1.6 \pm 0.28$ \\
\hline \multirow{4}{*}{ Diving beetle } & Chlorpyrifos & 120 & 100 & $44-267$ & $3.4 \pm 0.78$ \\
\hline & Permethrin & 120 & 45 & $31-68$ & $1.7 \pm 0.27$ \\
\hline & Cypermethrin & 120 & 8.3 & $5.9-11$ & $2.5 \pm 0.51$ \\
\hline & Bifenthrin & 100 & 5.4 & $3.9-7.7$ & $2.2 \pm 0.36$ \\
\hline
\end{tabular}

${ }^{a}$ Micrograms a.i. per liter of water; mortality assessed after $24 \mathrm{~h}$ of exposure.

b $95 \%$ confidence limit.

Levels of toxicity were similar for all taxa of aquatic insects and in the range of toxicity reported for other aquatic insects $[7,8]$, except the water scavenger beetle, which was five to 10 times less susceptible to all four compounds than the other insects.

\section{DISCUSSION}

The results of this investigation are the first report of LD50 values for aquatic insects that allow comparisons of toxicity between insects living in and out of an aquatic environment. The results of these comparisons indicate that susceptibility to insecticides is related to habitat and that aquatic insects are generally more susceptible to all the compounds, with the exception of the water scavenger beetle, which exhibited susceptibilities equal to or greater than those of the terrestrial species. This insect is perhaps more similar to the terrestrial insects, however, because it derives oxygen from the atmosphere. Adult scavenger beetles must return to the surface of the water periodically to replenish a bubble of air that provides oxygen during periods when they remain submerged.

For both terrestrial and aquatic insects, cypermethrin and bifenthrin were generally the most toxic of the tested compounds. The higher toxicity of the $\alpha$ - cyano-substituted pyrethroids (cypermethrin and bifenthrin) has been observed previously for both terrestrial and aquatic insects and may be related to increased stability to detoxification enzymes such as oxidases and hydrolases $[8,14]$. However, the level of differences between aquatic and terrestrial insects in susceptibility to topically applied insecticides was not as great as might be expected, given the extreme toxicities reported for aquatic insects when exposed to insecticide diluted in water. In addition, the conditions used to maintain insects during topical bioassays may have imposed a great deal of stress and resulted in increased susceptibility. Therefore, differences in toxicity between terrestrial and aquatic insects may be even less than estimated by topical application procedures.

The factors responsible for the extreme sensitivity of aquatic insects to pyrethroid insecticides diluted in water remain largely unknown. A potential contributing factor may be related to disruption of ionic balance [6], as pyrethroid insecticides have been shown to inhibit ATPase enzymes involved in movement of ions against concentration gradients [15]. Because freshwater aquatic organisms live in an extremely dilute environment, the processes involved in maintaining ionic balance and osmoregulation are critical to the maintenance of homeostasis. The processes whereby aquatic organisms maintain 
high cellular concentrations of ions against a concentration gradient are regulated by active transport [16]. The ATPase enzymes provide the energy necessary to active transport and are especially important at sites of oxygen exchange, such as the gills of fish and aquatic invertebrates [17].

In terrestrial organisms, the mode of action of pyrethroids is related to neurotoxicity caused by disruption of axonal transmission of nerve impulses as a result of altering ion permeability of nerve membranes [18]. Exposure of aquatic organisms to pyrethroids may also secondarily induce an osmotic imbalance that contributes to their toxicity. Similar effects have been reported in fish in which exposure to pyrethroids has been shown to disrupt respiratory surfaces and ion regulation $[17,19,20]$, although direct effects on ion movement have yet to be documented.

The conditions of the topical bioassays used in this study are probably not indicative of the response to exposure of aqueous solutions of insecticides and are more indicative of toxicodynamic differences in penetration, metabolism, and interaction with the target site. Aquatic insects have been suggested to possess lower capacities for detoxification of lipophilic xenobiotics such as insecticides [21], because there would be lower levels of exposure to lipophilic compounds in an aquatic environment. Reduced levels of xenobiotic-metabolizing enzymes in aquatic insects relative to terrestrial insects would be in agreement with the general trend of increased sensitivity of aquatic insects. It should be noted that the trend toward increased susceptibility of aquatic insects has some important exceptions, such as the high susceptibility of European corn borer to the pyrethroid insecticides; therefore, broad generalizations should be avoided.

Evidence in favor of increased sensitivity of aquatic insects to pyrethroid insecticides is further seen in the results of static exposure bioassays. In these tests, all three pyrethroid insecticides were more toxic than chlorpyrifos. These results contrast those from topical bioassays in which no consistent pattern of toxicity was observed for the four compounds and minor differences in susceptibility between chlorpyrifos and pyrethroids were observed. The differences between the two bioassay techniques may reflect differences in the way the insects are impacted by the insecticide. Because pyrethroids possibly affect ion movement as a result of ATPase inhibition and disruption of active transport, exposure to the insecticide under aqueous conditions may affect the insects' ability to maintain ion balance, re- sulting in increased susceptibility to this class of insecticides. Such effects would not be produced by the organophosphate insecticides such as chlorpyrifos, which are not known to inhibit ATPase or influence ion regulation.

Aquatic insects utilize a diversity of mechanisms for respiratory gas exchange [22]. Cutaneous respiration is probably important in many aquatic insects. An elaboration of large surface areas, the tracheal gills, has expanded the surface for cutaneous gas exchange in some groups. Many aquatic insects, however, obtain oxygen in much the same ways as terrestrial insects, and many simply come frequently to the water surface to replenish a bubble or film of air that can be maintained for extended periods below the surface. If pyrethroids adversely affect osmoregulation, different susceptibilities should be detected between gill-breathing and air-breathing aquatic insects, as was the case for water scavenger beetles. Although these insects spend much of their adult life submerged in an aquatic environment, oxygen is derived from the atmosphere; therefore, problems with osmoregulation would not be as great as they would be for gill-breathing insects, which rely on oxygen diffusion across the gill membrane. Differences in toxicity may also be influenced by cuticular composition, as water scavenging beetles are much more sclerotized and therefore may avoid toxicity by reduced penetration and adsorption of insecticide.

The results of this study indicate that pyrethroid insecticides are inherently more toxic to aquatic organisms. Differential toxicity may be related to differences in toxicodynamics of insecticide poisoning, although physiological and biochemical constraints associated with an aquatic mode of life may also be a factor. An increased understanding of the processes that influence susceptibility of aquatic organisms to pyrethroid insecticides is critical to the effective and safe use of these compounds.

\section{Acknowledgements}

The author thanks Terry Carlstrom, Alex Cunningham, James Jensen, Amy Manbeck, Midori Ono, Chris Renner, John Richman, and Tiffany Sieck for field collection and bioassays of aquatic insects, and Dr. Ken Pruess for identification of collection sites and critical review of this manuscript. Dr. Kyle Hoagland provided a valuable review of an earlier draft of this manuscript. Funding for this research was provided by the U.S. Geological Survey Section 104 Program and the University of Nebraska Water Center. 


\section{REFERENCES}

1 Casida, J.E., D.W. Gammon, A.H. Glickman, and L.J. Lawrence. 1983. Mechanisms of selected action of pyrethroid insecticides. Аnпи. Rev. Pharmacol. Toxicol. 23:413-438.

2 Larson, L.L., E.E. Kenaga, and R.W. Morgan. 1985. Commercial and Experimental Insecticides Entomological Society of America, College Park, MD

3 Bradbury, S.P. and J.R. Coats. 1982. Toxicity of fen valerate to bobwhite quail (Colinus virginianus) Including brain and liver levels associated with mortality $J$ Toxicol Environ Health $\mathbf{1 0}$ 307-319

4 Smith, T.M. and G.W. Stratton. 1986. Effects of synthetic pyrethroid insecticides on nontarget organisms Residue Rev 97 93-120

5 Elliott, M., N.F. James and C. Potter. 1978. The future of pyrethroids in insect control Annu Rev Entomol 23 433-469

6 Coats, J.R., D.M. Symonik, S.P. Bradbury, S.D. Dyer, L.K. Timson, and G.J. Atchison. 1989. Toxicology of synthetic pyrethroids in aquatic organisms An overview Environ Toxicol Chem 8 671-679

7 Anderson, R.L. 1989. Toxicity of synthetic pyrethroids to freshwater invertebrates Environ Toxicol Chem 8 403-410

8 Mokry, L.E. and K.D. Hoagland. 1990. Acute toxicities of five synthetic pyrethroid insecticides to Daphnia magna and Ceriodaphnia dubia Environ Toxicol Chem 9 1045-1051

9 Mian, L.S. and M.S. Mulla. 1992. Effects of pyrethroid insecticides on nontarget invertebrates in aquatic ecosystems $J$ Agric Entomol 9 73-98

10 McCarty, L.S., D. Mackay, A.D. Smith, G.W. Ozburn, and G.G. Dixon. 1992. Residue-based interpretation of toxicitiy and bioconcentration QSARs from aquatic bioassays Neutral narcotic organics Environ Toxicol Chem 11 917-930

11 Friant, S.L. and L. Henry. 1985. Relationship between toxicity of certain organic compounds and their concentrations in tissues of aquatic organisms A perspective Chemosphere 14 1897-1907

12 Nichols, J.W., J.M. McKim, M.E. Andersen, M.L. Gargas, H.J. Clewell III, and R.J. Erickson. 1990. A physlologically based toxicolki- netic model for the uptake and disposition of waterborne organic chemicals in fish Toxicol Appl Pharmacol 106 433-477

13 Raymond, M. 1985. Presentation d'une programme basic d'analyse log probit pour micro ordinateur Cah O R S T O M Ser Entomol Med Parasitol 23 117-121

14 Kahn, N.Y. 1983. An assessment of the hazard of synthetic pyrethroid insecticides to fish and fish habitat In J Miyamoto and P C Kearney, eds, Pesticide Chemistry Human Welfare and the Environment Vol 3-Mode of Action, Metabolism and Toxicology Pergamon, Elmsford, NY, pp $437-450$

15 Clark, J.M. and F. Matsumura. 1982. Two different types of inhibitory effects of pyrethrolds on nerve $\mathrm{Ca}^{-}$and $\mathrm{Ca}^{+} \mathrm{Mg}$ ATPase in the squid, Loligo pealei Pestic Biochem Physiol 4 232-238

16 Schmidt-Nielsen, K. 1985. Animal Physiology Adaptation and Environment, 3rd ed Cambridge University Press, New York, NY

17 Symonik, D.M., J.R. Coats, S.P. Bradbury, G.J. Atchison, and J.M. Clark. 1989. Effect of fenvalerate on metabolic ion dynamics in the fathead minnow (Pimephales promelas) and bluegill (Lepomis macrochirus) Bull Environ Contam Toxicol 42 821-828

18 Gray, A.J. and D.M. Soderlund. 1985. Mammalian toxicology of pyrethroids In D.H. Huston and T.R. Roberts, eds, Insecticides John Wiley \& Sons, New York, NY, pp 193-248

19 Dyer, S.D., J.R. Coats, S.P. Bradbury, G.J. Atchison, and J.M. Clark. 1989. Effect of water hardness and salinity on the acute toxicity and uptake of fenvalerate by bluegill ( Lepomis macrochirus) Bull Environ Contam Toxicol 42 359-366

20 Bradbury, S.P. and J.R. Coats. 1989. Toxicokinetics and toxicodynamics of pyrethroid insecticides in fish Environ Toxicol Chem 8 373-380

21 Nakatsugawa, T. and M.A. Morelli. 1976. Microsomal oxidation and insecticide metabolism In C.F. Wilkinson, ed., Insecticide Biochemistry and Physiology Plenum, New York, NY, pp 61-114

22 Nation, J.L. 1985. Respiratory systems In M.S. Blum, ed., Fundamentals of Insect Physiology John Wiley \& Sons, New York, NY, pp 185-226 